\title{
Trophic overlap between cohabiting populations of invasive mosquitofish and an endangered toothcarp at changing salinity conditions
}

\author{
Ana Ruiz-Navarro*, Mar Torralva, Francisco J. Oliva-Paterna \\ Departamento de Zoología y Antropología Física, Universidad de Murcia, 30100 Murcia, Spain
}

\begin{abstract}
Interspecific interactions can affect the long-term viability of endangered fish species. The present study analyses the interactions in trophic ecology between the endangered Iberian toothcarp Aphanius iberus and the highly invasive eastern mosquitofish Gambusia holbrooki at a sympatric site where they have been verified to coexist for more than $10 \mathrm{yr}$. The existence of a habitat gradient in the system, mainly determined by salinity and accompanied by different proportions of the 2 fish species, made it possible to analyse dietary variation along that gradient. Overall results from gut content analysis showed a high degree of similarity in the spring diets of both species. However, the mosquitofish appeared to be a better competitor for food resources, as individuals of this exotic species presented a lower proportion of empty guts and their guts contained more food. Possibly associated with a certain degree of spatial segregation, a shift in the diet composition of the toothcarp and the mosquitofish was observed among sites with different salinities and relative abundances of both species. In general, in sectors of the channel with lower salinity levels and mosquitofish as the dominant species, toothcarp seemed to display more benthic feeding and, consequently, the diets of both species were less overlapped. Under such conditions, the toothcarp diminished feeding intensity and diet diversity. Thus, this native species could be subjected to a decrease in its population viability as a direct consequence of trophic relationship with the invasive fish.
\end{abstract}

KEY WORDS: Aphanius iberus · Gambusia holbrooki · Diet · Trophic ecology · Interaction

\section{INTRODUCTION}

Although invasive freshwater fish are among the main causes of the worldwide decline of aquatic native fauna (Gozlan et al. 2010), there is still much to learn regarding their direct interactions and impacts (García-Berthou 2007). The management of many invasive species and predictions about their impacts in future invasions could benefit from detailed studies of their biology and ecology in invaded habitats (Olden et al. 2006). The importance of interspecific interactions with invasive species has been highlighted when threatened fish species are involved (Ribeiro \& Leunda 2012), because such interactions could affect their population viability (e.g. Leunda 2010, Carmona-Catot et al. 2013).

The present study used 2 paradigmatic species as models in order to increase the knowledge of interactions in trophic ecology between invasive and endangered fish. The Iberian toothcarp Aphanius iberus (Valenciennes, 1846) is a cyprinodontid fish endemic to the Iberian Peninsula, catalogued as 'Endangered' (IUCN 2011) and protected by international laws (Oliva-Paterna et al. 2006). The presence of the eastern mosquitofish Gambusia holbrooki Girard, 1859, a highly invasive poeciliid fish, has contributed to the reduction or elimination of native fauna worldwide (revised by Pyke 2005, 2008) and has been high- 
lighted as a direct factor in the decline of toothcarp populations (Oliva-Paterna et al. 2006). In experimental studies carried out in aquaria and mesocosms, mosquitofish compete for food with toothcarp, prey on its eggs and juveniles, display aggressive behaviour towards adults and juveniles, interfere in its reproductive behaviour and promote habitat exclusion (Rincón et al. 2002, Caiola \& de Sostoa 2005, Carmona-Catot et al. 2013). In relation to this, toothcarp is less abundant in areas where mosquitofish is present and its habitat use is also altered (Clavero et al. 2007). Additionally, mosquitofish alter habitat and community structures, affecting the availability and access to food and other resources (Margaritora et al. 2001, Alcaraz et al. 2008a). Among other factors, competition for food between toothcarp and mosquitofish is probably one of the main causes of the native fish's decline (Rincón et al. 2002, Caiola \& de Sostoa 2005); however, no study has previously explored their trophic relationship in natural conditions.

Mosquitofish is, at present, the most abundant, widespread freshwater fish in the world, due to it being widely tolerant to an exceptional range of environmental conditions (Haynes \& Cashner 1995, Pyke 2008). Among others, its tolerance to high temperature, acid and basic $\mathrm{pH}$, or low dissolved oxygen (Homski et al. 1994, Pyke 2008) can be highlighted. Mosquitofish is also able to survive a wide range of salinities (Purcell et al. 2008), and even established mosquitofish populations have been described in eusaline and hypersaline waters (Alcaraz \& GarcíaBerthou 2007a, Ruiz-Navarro et al. 2011, 2013). However, salinity is one of the most stressful factors in the viability of mosquitofish populations, and the disrupting effects of salinity on the species' biology have been described (Alcaraz \& García-Berthou 2007a, Ruiz-Navarro et al. 2013). Tolerance to salinity is wider in Iberian toothcarp, and, in fact, its current distribution is mostly concentrated in saline aquatic systems (Oliva-Paterna et al. 2006, Alcaraz \& García-Berthou 2007a, Alcaraz et al. 2008b). In relation to this, and according to the results of CarmonaCatot et al. (2013), interrelationships between mosquitofish and native species may also be affected by salinity. Thus, understanding the interactions between toothcarp and mosquitofish under different salinity conditions will have important management implications for their respective control and recovery programmes.

The San Pedro del Pinatar wetland in the southeastern Iberian Peninsula offers an ideal opportunity to study the trophic relationship between Iberian toothcarp and eastern mosquitofish at different sal- inity conditions, because it presents a temporarily stable spatial gradient of water salinity, and the fish community is almost exclusively made up of wellestablished populations of Iberian toothcarp and eastern mosquitofish. The aim of this study was to analyse some traits of the trophic ecology of both species in sympatric populations that have cohabited a saline system for $>10 \mathrm{yr}$, and the specific objectives were: (1) to analyse the diet composition and overlap between both species in sympatric populations and (2) to test whether interactions in trophic ecology differed among the sites established along a gradient of water salinity and the relative abundance of both species, considering the intensity and overlap of trophic indices.

\section{MATERIALS AND METHODS}

\section{Study area and sampling sites}

San Pedro del Pinatar is a protected wetland located on the northern edge of the Mar Menor coastal lagoon (SE Iberian Peninsula, UTM $30 \mathrm{~S}$ 6961034189171 ) that is mainly constituted by saltworks. There is a $3200 \mathrm{~m}$ long and 4 to $5 \mathrm{~m}$ wide peripheral channel that acts as a barrier between the adjacent drainage basin and the salt evaporation ponds. The channel presents water permanently, in lentic conditions, with no tidal influence and a variable depth from 30 to $40 \mathrm{~cm}$ in the sector close to its mouth, where marine intrusion occasionally occurs, to 20 to $30 \mathrm{~cm}$ at its opposite end. It is usually isolated from the salt evaporation ponds, although it has been used for their drainage on specific occasions. This channel also receives direct inputs from the sewer system (rainwater) and, in the sector close to its mouth, intermittent freshwater inputs from the San Pedro del Pinatar domestic wastewater treatment plant. Along most of its extension, the channel presents an artificial substrate (concrete) covered by mud and sand. The predominant aquatic vegetation is represented by floating mats of filamentous algae, mainly Cladophora sp., the coverage of which increases with rising temperatures. The channel banks are comprised of stones with some patches of the common reed Phragmites australis. Only toothcarp Aphanius iberus and mosquitofish Gambusia holbrooki have maintained permanent populations in the channel, and their coexistence at this sympatric site has been verified since 1998 (Torralva et al. 2001). However, the European eel Anguilla anguilla (Linnaeus, 1758) and members of the Mugilidae 
family-mainly Liza saliens (Risso, 1810) and L. aurata (Risso, 1810) - are occasionally observed in very low densities and homogeneously distributed in the channel. Water salinity values are usually temporarily stable with a longitudinal gradient along the channel (authors' unpubl. data).

Sampling for the present study was performed in 3 stretches selected along the habitat gradient mainly determined by water salinity: 1 internal site (CSP1), close to the end of the channel, and 2 sites in the intermediate sector of the channel (CSP2 and CSP3). In order to examine differences among subpopulations along the habitat gradient, each sampling site in the present study covered $<80 \mathrm{~m}$ in length and sites were a minimum of $600 \mathrm{~m}$ apart, based on previous studies that pointed to home-ranges of mosquitofish and toothcarp smaller than $250 \mathrm{~m}$ (Law et al. 1994, Chapman \& Warburton 2006, Alcaraz et al. 2008b).

\section{Sampling methodology}

For the year included in the present study (autumn 2007 to summer 2008), temperature $\left({ }^{\circ} \mathrm{C}\right.$ ) and water salinity were registered seasonally by a WTW-400 ${ }^{\circledR}$ multiparameter probe. Fish relative abundances were assessed monthly at each site from February to May 2008; 10 minnow-traps (1 mm mesh size) (Harrison et al. 1986) were set for roughly $24 \mathrm{~h}$ and hand nets ( $1 \mathrm{~mm}$ mesh size) were used to sieve for $10 \mathrm{~min}$. The total number of fish captured was counted and expressed as catch per unit of effort (CPUE), 1 unit of effort being 10 traps in place for $24 \mathrm{~h}$ together with $10 \mathrm{~min}$ of sieving.

The fish survey for diet study was performed in March 2008, when the population dynamics of both fish species were in a phase dominated by large individuals and just in the pre-reproduction period (RuizNavarro et al. 2011, Gascón et al. 2013). Thus, on the morning of 12 March 2008, a total of 91 toothcarp individuals (32 in CSP1, 27 in CSP2 and 32 in CSP3) and 107 mosquitofish (37 in CSP1, 34 in CSP2 and 36 in CSP3) were captured by hand net $11 \mathrm{~mm}$ mesh size) for diet analysis. They were anesthetised with benzocaine, fixed in buffered $10 \%$ formaldehyde and preserved in $70 \%$ ethanol.

The sampling to analyse prey availability was carried out on the morning of the same day. As it is known that the diets of toothcarp and mosquitofish are mainly based on organisms from the water column and epibenthos (Alcaraz \& García-Berthou 2007b, Blanco et al. 2004), invertebrates from these microhabitats were sampled with a hand net $(250 \mu \mathrm{m}$ mesh size). A constant effort of 20 passes with the hand net was performed at each site, sampling all the different detected microhabitats proportionally to their abundance. The samples were fixed in buffered $4 \%$ formaldehyde and transported to the laboratory for invertebrate classification.

\section{Laboratory methodology}

All fish captured for diet study were sexed (male, female, or immature), measured (total length, $L_{\mathrm{T}}$, $\pm 1 \mathrm{~mm}$ ) and weighed (total mass, $M_{\mathrm{T}} \pm 1 \mathrm{mg}$ ), and their gut contents were examined under a stereomicroscope. The size structure of the specimens randomly selected for diet analysis were similar; the mean length of the toothcarp was $27.0 \pm 0.8 \mathrm{~mm} L_{\mathrm{T}}$ (range: $20-37 \mathrm{~mm}$ ) and the mean length of the mosquitofish was $26.2 \pm 0.8 \mathrm{~mm} L_{\mathrm{T}}$ (range: $17-38 \mathrm{~mm}$ ). Prey items were classified to the lowest taxonomic level possible, counted and up to 25 individuals of each taxon (if available) were measured $\left(L_{\mathrm{T}}\right.$, $\pm 0.02 \mathrm{~mm}$ ) under a stereomicroscope using an ocular micrometer. The measurements were converted to dry mass according to published length-dry mass relationships. The volume of uncountable categories was estimated to the nearest $0.00025 \mathrm{~mm}^{3}$ with a Neubauer counting chamber and later transformed to biomass using a conversion of $0.27 \mathrm{mg}$ dry mass $\mathrm{mm}^{-3}$ (García-Berthou 1999, Alcaraz \& García-Berthou 2007b).

Invertebrates captured to study prey availability were identified at least to the family level, except for microcrustaceans, which were identified to a higher level. All organisms were counted, and up to 25 individuals of each taxon (if available) were also measured. The measurements were converted to dry mass according to published length-dry mass relationships.

\section{Data analysis}

Invertebrate diversity available in the habitat was calculated by applying Simpson's index $(D)$ (Simpson 1949) to biomass data of invertebrates, as:

$$
D=\sum_{i} \frac{b_{i}\left(b_{i}-1\right)}{B(B-1)}
$$

where $b_{i}$ is the biomass of invertebrate $i$ and $B$ is the total biomass of invertebrates. In this index, 0 represents maximum diversity and 1 minimum diversity. 
To estimate feeding intensity, the proportion of empty guts and a fullness index were used. The proportion of empty guts in the total number of guts examined was compared between species and sites (chi-square tests). The fullness index (FI\%) was estimated for each individual as the percentage ratio of the total biomass of gut contents of a fish to its total body mass (Carpentieri et al. 2007). To identify differences in FI\%, values were compared (arcsine transformed) between species and sites by ANOVA (Bonferroni post hoc tests).

Frequency of occurrence $(F \%)$, percent number $(N \%)$ and percent biomass $(B \%)$ were calculated in order to determine the importance of each food category to the diet of the fish species. $F \%$ is the percentage of guts in which a food category was present. $N \%$ is the number of prey items of a food category divided by the total number of prey items and expressed as a percentage after pooling the gut contents of all fish. $B \%$ is the equivalent index for biomass data. Feeding strategy diagrams were constructed following Costello (1990) to describe prey importance.

Differences in diet composition were assessed by analysis of similarities (ANOSIM), using similarity matrices based on the Bray-Curtis similarity coefficients generated from prey item biomass data (previously square-root transformed). Prey representing $<1 \%$ of total biomass were excluded from the analysis. Diet diversity for each fish was assessed by applying $D$ to biomass data of the prey. It was contrasted (arcsine transformed) between species by ANOVA and between sites for each species by analysis of covariance (ANCOVA, with $L_{\mathrm{T}}$ as the covariate, to account for size effects). In the ANCOVA analyses, non-significant interactions were removed from the models to increase the statistical power of the remaining sources. If the covariate was not significant, it was also removed, and an ANOVA was used (García-Berthou \& Moreno-Amich 1993).

Vanderploeg \& Scavia's (1979) relativised electivity index $(E)$ was used to contrast diet composition with prey availability:

$$
E_{i}=\frac{\left[W_{i}-(1 / n)\right]}{\left[W_{i}+(1 / n)\right]} ; W_{i}=\frac{p_{i} / a_{i}}{\sum p_{i} / a_{i}}
$$

where $E_{i}$ is the electivity of predator for prey $i, p_{i}$ is the relative (proportional) biomass of prey $i$ in the diet, $a_{i}$ is the relative biomass of prey $i$ in the environment and $n$ is the number of prey types included in the analysis. This index ranges from -1 (negative selection) to +1 (positive selection), and values near zero indicate neutral electivity (the fish consume the prey relative to its availability). To test whether electivity significantly deviated from zero, Student's $t$-tests were used. Electivity for each prey type was compared (arcsine transformed) between species by ANOVA (Alcaraz \& García-Berthou 2007b). This index could be calculated only for organisms captured from the environment.

In order to complete the diet overlap analysis between the fish species, the Morisita-Horn index (C) (Morisita 1959, Horn 1966) was used based on prey biomass data, calculated as:

$$
\mathrm{C}_{h j}=\frac{2\left(\sum p_{h i} \cdot p_{j i}\right)}{\sum p^{2} h i \cdot p^{2}{ }^{2}}
$$

where $C_{h j}$ is the similarity between the predator species $h$ and $j, p_{h i}$ and $p_{j i}$ are the relative biomasses of prey $i$ in the diets of predators $h$ and $j$. Diet overlap ranges from 0 (no overlap) to 1 (complete overlap) (Keast 1977, Wallace 1981).

The ANOSIM was performed with the statistical package PRIMER $6{ }^{\circledR}$ V.6.1.12, while the rest of the analyses were performed using the statistical package $\operatorname{SPSS}^{\circledR}$ v.15.0.

\section{RESULTS}

\section{Habitat characteristics}

For the annual cycle, mean salinity values were 24.62 at CSP1, 14.46 at CSP2 and 12.66 at CSP3, confirming the expected longitudinal gradient. Temperature (Fig. 1A) and aquatic vegetation coverage, however, did not differ among sites. The relative abundance of mosquitofish (CPUE $=39.2$ ) was greater than that of toothcarp (CPUE = 14.3). However, the proportions (toothcarp/mosquitofish) varied among sites (CSP1: 25/9; CSP2: 10.5/52.5; CSP3: 7.5/56) (Fig. 1C).

\section{Prey availability}

The invertebrate community sampled across sites was dominated by Gammarus aequicauda (Martynov, 1931) (O. Amphipoda, Fam. Gammaridae) and naidids (Subcl. Oligochaeta, Fam. Naididae). But there were also other species present, such as Lekanesphaera hookeri (Leach, 1814) (O. Isopoda, Fam. Sphaeromatidae), chironomid larvae (O. Diptera, Fam. Chironomidae), ostracods (Cl. Ostracoda) and cyclopoids (O. Cyclopoida) (Fig. 1B). Invertebrate diversity at the 3 sampling sites was $D=0.553,0.448$ 

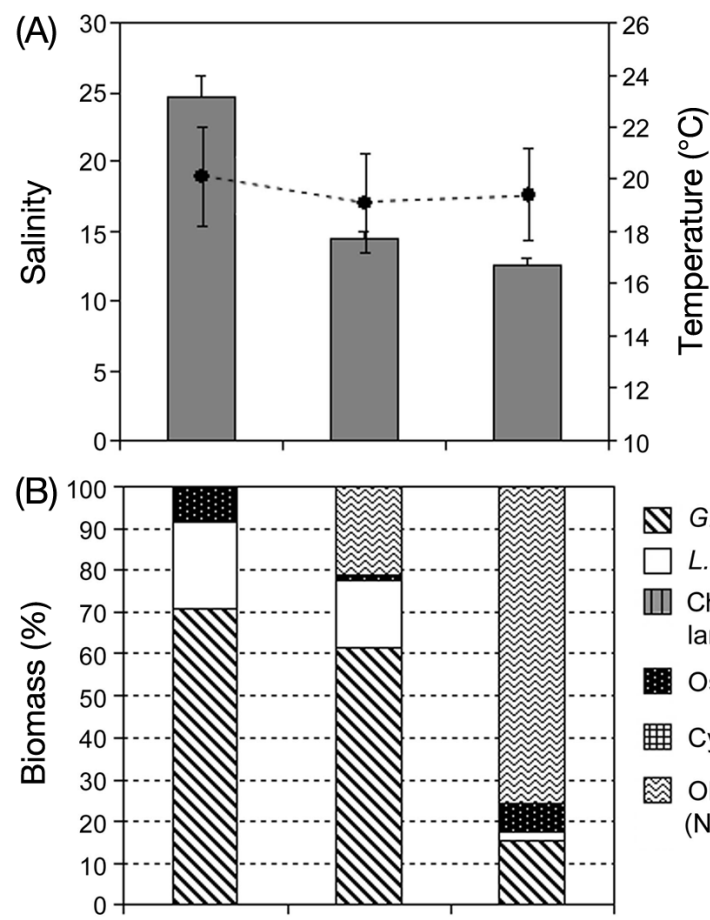

\$ G. aequicauda $\square$ L. hookeri

四 Chironomid larvae

Ostracoda

㻃 Cyclopoida

Oligochaeta (Naididae)

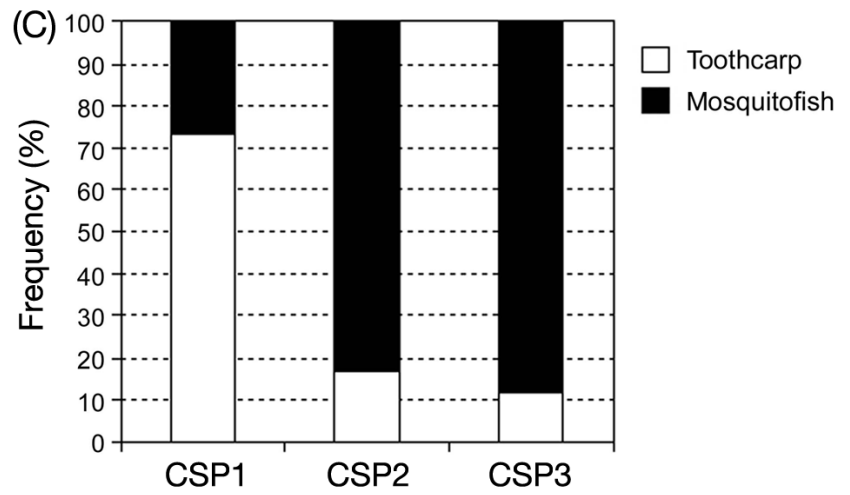

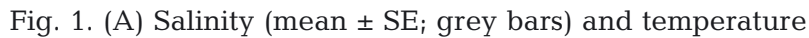
(mean $\pm \mathrm{SE}$; dashed line), (B) relative biomass of the various invertebrate taxa captured as prey availability and $(\mathrm{C})$ relative abundance of the 2 fish species (toothcarp Aphanius iberus and mosquitofish Gambusia holbrooki) at the 3 sampled sites (CSP1, CSP2 and CSP3)

and 0.602, for CSP1, CSP2 and CSP3, respectively; with no differences to the mean $( \pm S E)$ value of the channel $(0.535 \pm 0.045)$ (Student's $t$-test; CSP1: $\mathrm{p}=$ 0.721; CSP2: $\mathrm{p}=0.198$; CSP3: $\mathrm{p}=0.275)$. However, both the total invertebrate biomass (CSP1 = $114023.25 \mu g ;$ CSP2 = $1135725.19 \mu g_{i}$ CSP3 = $1229500.14 \mu \mathrm{g})$ and the relative importance of the principal taxa varied among sites $\left(\chi^{2}=152.16\right.$, $\mathrm{p}<$ $0.001)$, mainly due to a gradual increase of Oligochaeta and a gradual decrease of $G$. aequicauda from CSP1 to CSP2 and CSP3 (Fig. 1B).

\section{Interactions in trophic ecology: channel approach}

In the comparison between the trophic indices of each species in the overall channel populations (i.e. across the 3 sites), assuming that toothcarp and mosquitofish have relatively similar rates of digestion, toothcarp showed a higher proportion of empty guts $(9: 91)$ than mosquitofish $(2: 107)\left(\chi^{2}=6.03, \mathrm{p}=\right.$ $0.014)$, and FI\% was significantly higher in the latter (toothcarp: FI $\%=0.130$; mosquitofish: FI $\%=0.318$; ANOVA: $\left.F_{1,194}=31.01, \mathrm{p}<0.001\right)$.

Diet diversity, estimated as the mean value of the individuals' $D$ values, did not significantly differ between toothcarp (0.883) and mosquitofish (0.838) (ANOVA $F_{1,183}=3.19, \mathrm{p}=0.076$ ), and was relatively low in both cases. ANOSIM analysis based on biomass data showed a significant degree of similarity between the diet compositions of both species in the channel (global $\mathrm{R}=0.021, \mathrm{p}=0.105$ ). In relation to this, both species were omnivorous. Their diets were dominated by Gammarus aequicauda and, to a lesser extent, Lekanesphaera hookeri, although the most common food items of mosquitofish also included chironomid larvae and pupae, Homoptera and nonaquatic (terrestrial and aerial) insects captured from the water surface (Table 1, Fig. 2). The rest of the prey categories were rare in both fish species. However, despite this similarity, population data presented in Table 1 intuitively suggest that mosquitofish fed more broadly than toothcarp.

In the prey electivity analysis, the toothcarp displayed neutral electivity for Gammarus aequicauda (Student's $t$-test: $\mathrm{p}=0.269$ ) and significant negative electivity ( $p<0.05$ ) for Lekanesphaera hookeri, chironomid larvae, Ostracoda, Cyclopoida and Oligochaeta. The mosquitofish showed significant positive electivity for $G$. aequicauda $(p=0.011$ ) and significant negative electivity $(\mathrm{p}<0.05)$ for the other 5 categories. Electivity for $G$. aequicauda was higher in the mosquitofish (ANOVA: $F_{1,196}=6.30, \mathrm{p}=0.013$ ), while no difference in electivity between fish species was found for the remaining prey categories (ANOVA: $p$ > 0.05). The degree of diet overlap in the channel between both fish species was close to $50 \%(C=0.47)$.

\section{Interactions in trophic ecology in changing salinity conditions}

With a spatial approach, Table 2 represents the comparison among sites in the trophic indices for each species. The proportion of empty guts in the toothcarp was significantly higher at CSP3; in con- 
Table 1. Diet of toothcarp Aphanius iberus and mosquitofish Gambusia holbrooki in the peripheral channel of the San Pedro wetland. $F \%$ : frequency of occurrence $N \%$ : percent number; $B \%$ : percent biomass. In toothcarp 82 from 91 guts contained food, in mosquitofish this was 105 out of 107

\begin{tabular}{|lccccccc|}
\hline & \multicolumn{3}{c}{ Toothcarp } & \multicolumn{3}{c|}{ Mosquitofish } \\
& $F \%$ & $N \%$ & $B \%$ & $F \%$ & $N \%$ & $B \%$ \\
\hline Gammarus aequicauda & 49.21 & 42.25 & 66.84 & 46.32 & 20.22 & 21.92 \\
Lekanesphaera hookeri & 29.37 & 46.92 & 10.70 & 21.05 & 19.44 & 1.76 \\
Chironomid larvae & 1.59 & 10.83 & 1.62 & 0.53 & 5.48 & 10.28 \\
Chironomid pupae & 0.00 & 0.00 & 0.00 & 2.11 & 6.84 & 22.64 \\
Culicid larvae & 0.00 & 0.00 & 0.00 & 0.53 & 5.48 & 0.04 \\
Homoptera & 0.00 & 0.00 & 0.00 & 4.74 & 12.17 & 4.16 \\
Collembola & 0.00 & 0.00 & 0.00 & 3.68 & 7.04 & 1.09 \\
Ostracoda & 0.00 & 0.00 & 0.00 & 1.58 & 5.48 & 0.84 \\
Benthic diatoms & 0.79 & 0.00 & 1.58 & 0.00 & 0.00 & 0.00 \\
Non-aquatic insects & 0.00 & 0.00 & 0.00 & 10.00 & 12.39 & 6.34 \\
Detritus & 12.70 & & 11.14 & 3.16 & & 4.80 \\
Plant debris & 6.35 & & 8.11 & 3.16 & & 0.25 \\
Other & 0.00 & 0.00 & 0.00 & 3.16 & 5.48 & 25.88 \\
\hline
\end{tabular}

trast, the mosquitofish had a similar proportion of empty guts at the 3 sampled sites. Results also indicated that the feeding intensity of the toothcarp according to FI\% presented spatial differences and was higher at CSP1. The fullness index was similar for the mosquitofish at all of the sites (Table 2).

The spatial factor significantly affected toothcarp's diet diversity and was higher (lower values of $D$ ) at CSP1, although no differences among sites were detected in $D$ for the mosquitofish (Table 2). Accordingly, the diet composition of the toothcarp presented differences among sites that were deter-
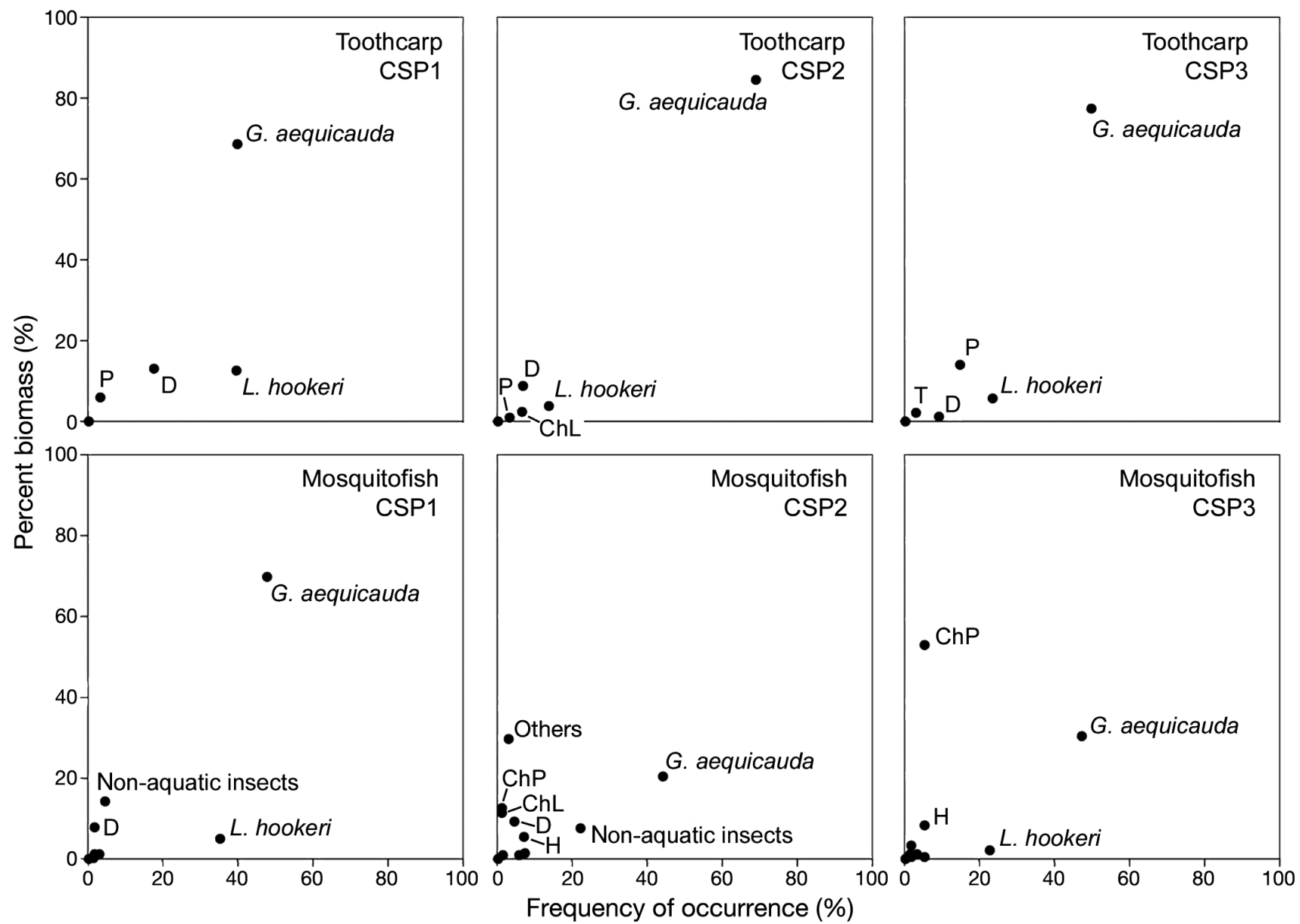

Fig. 2. Relationships between prey percent biomass $(B \%)$ and frequency of occurrence $(F \%)$ of food categories of toothcarp Aphanius iberus and mosquitofish Gambusia holbrooki diets at each sampled site (CSP1, CSP2 and CSP3). Plots based on Costello's (1990) method. ChL: chironomid larvae; ChP: chironomid pupae; D: detritus; H: Homoptera; P: plant debris; 
Table 2. Comparison of the trophic indices of toothcarp Aphanius iberus and mosquitofish Gambusia holbrooki among sites in the peripheral channel of the San Pedro wetland (in changing salinity conditions)

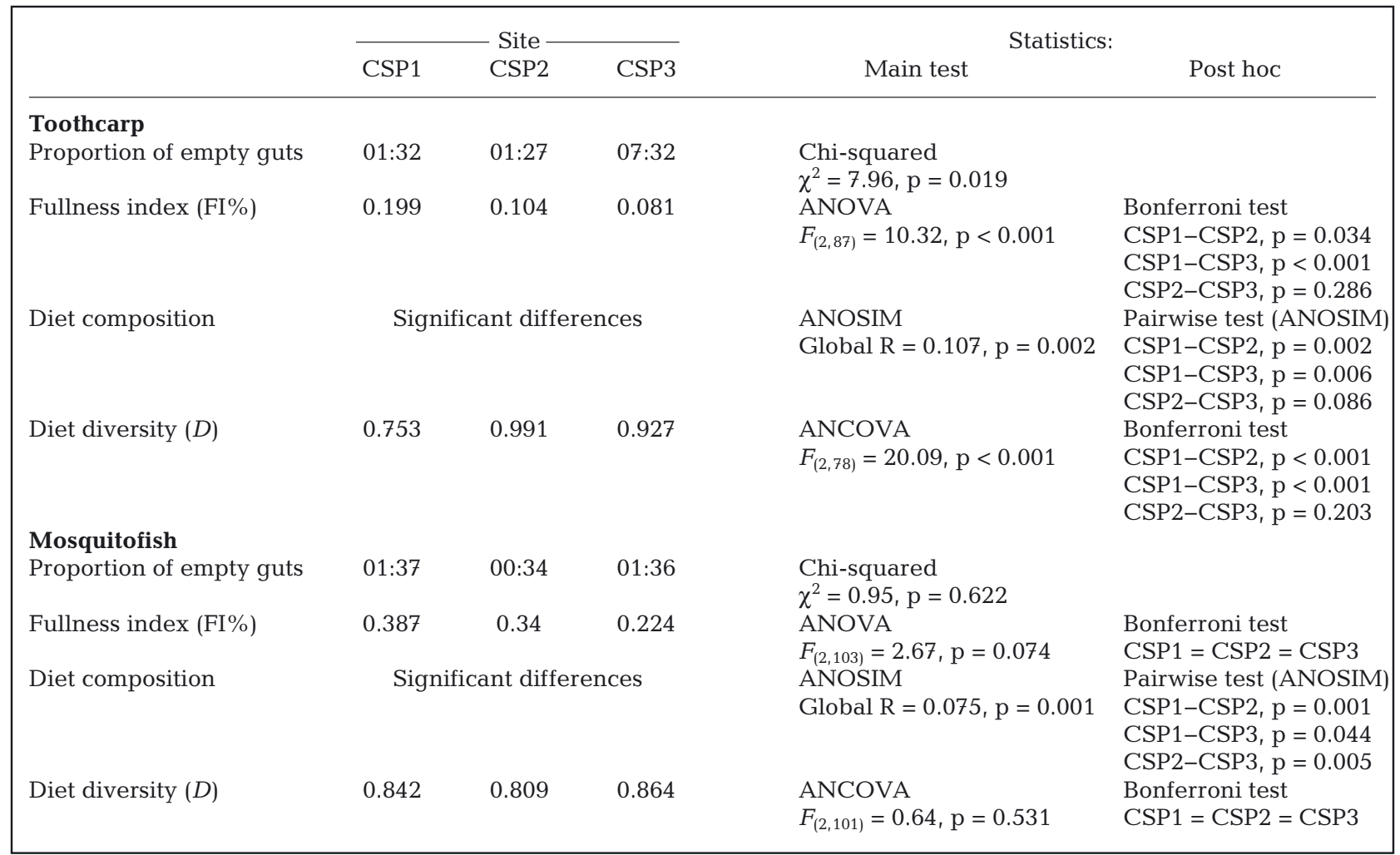

mined mainly because CSP1 was distinct from the other 2 sites, as the pairwise ANOSIM tests demonstrated (Table 2). In this sense, the most important prey for the toothcarp at CSP1 was Gammarus aequicauda, but Lekanesphaera hookeri appeared with the same frequency and detritus was also quite important in biomass (Fig. 2). However, in CSP2 and CSP3, the diet of this fish species was mainly based on $G$. aequicauda; the importance of $L$. hookeri and detritus in the diet was clearly reduced; chironomid larvae appeared (in CSP2), and plant debris became more important (in CSP3). On its part, the diet composition of the mosquitofish differed at each of the 3 sampled sites (Table 2). At CSP1, diet was mainly based on $G$. aequicauda (Fig. 2), followed in prey importance by L. hookeri and non-aquatic insects. At CSP2, the food items classified as 'other' (parts of organisms, chironomid pupal exuviae, etc.) together with chironomid larvae, chironomid pupae and nonaquatic insects became more important at the expense of $G$. aequicauda and L. hookeri. Finally, at CSP3, chironomid pupae were the prey type that most contributed to differences, and, in terms of biomass, they were clearly more important in the diet than $G$. aequicauda (Fig. 2).
In respect to prey electivity, toothcarp presented a neutral electivity (no selection) for the most important food item in its diet, Gammarus aequicauda, at the 3 sites (Fig. 3). Lekanesphaera hookeri underwent neutral electivity at CSP1 by this fish species, but negative at CSP2 and CSP3, where the toothcarp also negatively selected chironomid larvae. Ostracoda, Cyclopoida and Oligochaeta were not eaten by the toothcarp at any site, so they underwent absolute negative electivity $(E=-1)$ when present. The mosquitofish positively selected $G$. aequicauda at CSP2 and neutrally at CSP1 and CSP3 (Fig. 3). L. hookeri experienced negative electivity by this fish species, and showed lower values at CSP2. Chironomid larvae and Ostracoda were negatively selected at all of the sites where they were present, and, finally, Cyclopoida and Oligochaeta were not consumed by the mosquitofish at any site (Fig. 3).

Spatial approach to diet overlap between the toothcarp and mosquitofish as assessed using $C$ demonstrated differences among sites. In this sense, the diets of the toothcarp and mosquitofish were highly overlapped at CSP1 $(C=0.97)$, although the degree of overlap was lower at CSP2 $(C=0.41)$ and CSP3 $(C=0.47)$. 

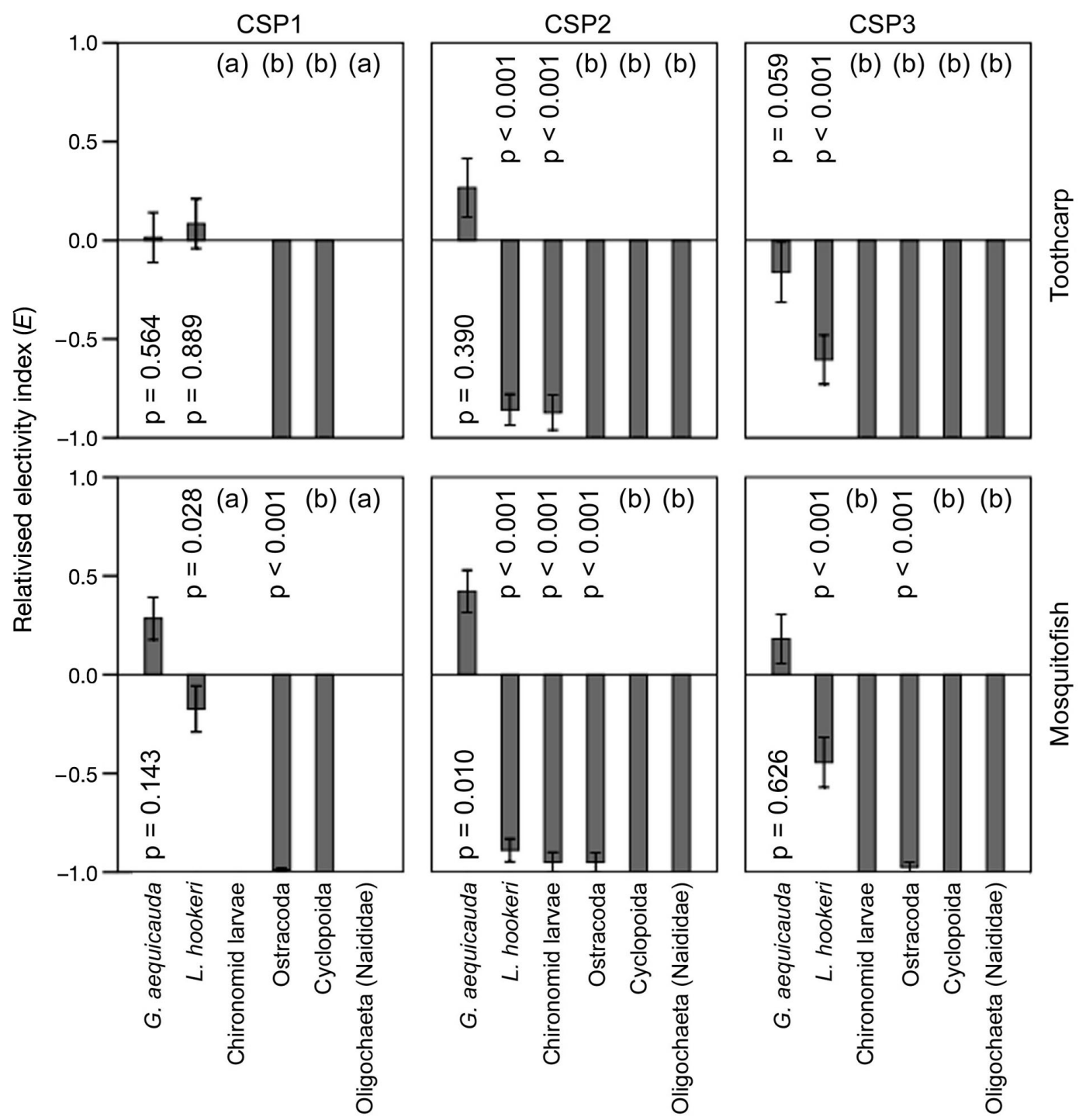

Fig. 3. Relativised electivity index $(E$; mean $\pm \mathrm{SE}$ ) for each prey type by each fish species (toothcarp Aphanius iberus and mosquitofish Gambusia holbrooki) at each sampled site (CSP1, CSP2 and CSP3). Student's t-tests (p $\leq 0.05)$ were done to determine if electivity was significantly different from neutral (0), and p-values are presented. (a): this prey type was not captured from the environment; (b): this prey type was not eaten by fish

\section{DISCUSSION}

Along the studied channel, toothcarp had a higher proportion of empty guts and, on average, their guts contained less food than those of mosquitofish. These results agree with previous aquaria and mesocosm studies, where it has been observed that mosquitofish present higher levels of satiety and voracity than toothcarp and thus a greater foraging ability and overall competitive advantage (Caiola \& de Sostoa 2005). The higher competitive advantage of mosquitofish in capturing food, along with its aggressive behaviour, makes it a better competitor than the native species for available invertebrates (Haas et al. 2003). In this study, at sites where salinity values were $<15$ and the mosquitofish was more abundant than the toothcarp, the guts of the latter contained less food and they presented the highest proportion of empty guts despite greater trophic availability. However, the proportion of empty guts and the fullness index in mosquitofish did not vary among sites. Although other environmental factors may have affected the observed changes among sites, these results can be explained in relation to those obtained by Alcaraz et al. (2008a), who demonstrated that mosquitofish increased their aggressive behaviour 
towards toothcarp at lower salinities. Caiola \& de Sostoa (2005) related the increased empty guts in toothcarp with decreased survival rates of its individuals. Furthermore, a direct relationship between gut biomass and somatic condition in this species has been found (Alcaraz et al. 2008b). The influence of diet and food intake on different growth and reproduction traits has been stated for other cyprinodontiform species (e.g. Trendall 1983, Wurtsbaugh \& Cech 1983). Consequently, and in accordance with the results of the present study, it can be predicted that at sites with salinity values $<15$ where the mosquitofish is more abundant than the toothcarp, the native species could be subject to a detriment in somatic condition, survival rate and possibly an alteration of its population's reproductive ability. In addition, other studies have demonstrated that interaction with mosquitofish causes alterations in the biological parameters of native species, such as growth or recruitment (e.g. Howe et al. 1997, Mills et al. 2004).

The observed diets of the toothcarp and mosquitofish along the San Pedro wetland channel reflected the omnivorous and generalist character described for both fish species on the Iberian Peninsula (e.g. García-Berthou 1999, Vargas \& de Sostoa 1999, Alcaraz \& García-Berthou 2007b). In general terms, following their respective feeding patterns (Arthington 1989, Alcaraz \& García-Berthou 2007b), both were mainly based on water column organisms but differed between them in the use of benthos and organisms from the water surface. These differences are likely to be mainly determined by differences in habitat use. The respective preferences of toothcarp for vegetated areas and mosquitofish for open waters have been described (Miura et al. 1979, Alcaraz et al. 2008b), and experiments in aquaria (Rincón et al. 2002) have shown that toothcarp preys more on benthic forms in the presence of mosquitofish, which occupies a higher position in the water column. Diet diversity was relatively low for both fish species. In comparison to other systems, the diet diversity of the toothcarp in the San Pedro channel was much lower than in the Fra Ramon coastal lagoon, where this fish species was the only stable population (Alcaraz \& García-Berthou 2007b). However, the low diet diversity observed in this study could also be related to the narrow range of available invertebrate prey in the system; this could explain the low diet diversity found in the mosquitofish here compared to previous studies which indicated that this generalist species often feeds quite broadly (GarcíaBerthou 1999, Gkenas et al. 2012).

Differences among sites in the abundances of Gammarus aequicauda and Lekanesphaera hookeri in the diets of both fish species cannot be assigned directly to the proportions of these invertebrates in the environment. Since Gammarus individuals compete for the refuge that substratum provides, their average size is usually higher in the benthos than in the water column (Van Dolah 1978, Newman \& Waters 1984, Morillo-Velarde et al. 2011). On the assumption that this pattern is similar in G. aequicauda, the increase of the G. aequicauda biomass consumed by the toothcarp and the diminution of such consumption in the mosquitofish could reflect a shift in feeding strategy with reduced salinity. In this sense, the toothcarp would present more benthic feeding at sites with salinity values $<15$ and where mosquitofish was the dominant species. Accordingly, the degree of overlap between the diets of the toothcarp and the mosquitofish was lower in such conditions. Despite the small number of sites examined, these results support findings from aquarium experiments of spatial segregation when both fish species coexist (Rincón et al. 2002), and point to the fact that such spatial segregation also seems to be related to the relative abundance of fish and to the aggressive behaviour of mosquitofish as mediated by salinity (Alcaraz et al. 2008a). The subsequent segregation into trophic niches could favour the coexistence of both species, as suggested by Moreno-Amich et al. (1999).

Despite their generalist feeding strategy, mosquitofish and toothcarp are able to exhibit selection in their feeding behaviours by consuming prey species in proportions that differ from the availability of those items in the environment (Miura et al. 1979, Alcaraz \& García-Berthou 2007b). However, the results obtained in the prey electivity analysis in the San Pedro wetland channel did not permit clear interpretation. With the exception of the positive selection that mosquitofish presented for Gammarus aequicauda at one site (CSP2), both fish species presented neutral or negative selection for all of the studied prey types. Moreover, in the spatial comparison, only electivity for Lekanesphaera hookeri was slightly different among sites.

In conclusion, the invasive mosquitofish appeared to be a better competitor for food resources than the native toothcarp, displaying higher feeding intensity. Furthermore, the feeding intensity of the toothcarp, which has been positively related to survival and reproductive rates in previous studies, decreased significantly when salinity was $<15$ and mosquitofish were more abundant. Therefore, the native species could be subject to a decrease in its population viability as a direct consequence of interaction with the exotic species. 
However, a shift in the composition of toothcarp and mosquitofish diets associated with salinity and with their relative abundance was observed in the present study. In general terms, in areas of the channel with salinity values $<15$ and mosquitofish as the dominant species, the toothcarp showed diminished diet diversity and possibly more benthic feeding. Thus, it is shown how the invasive ability of mosquitofish, also in regard to its feeding ecology, is related to salinity, being reduced at higher saline conditions. Consequently, these results highlight the importance of the conservation and restauration of saline habitats, for both the conservation of the Iberian toothcarp and other Iberian cyprinodontids and the control of the mosquitofish.

On the other hand, despite the high degree of interspecific overlap that exists between the 2 fish species along the studied channel, the results point to a relative spatial segregation of their trophic niches that, together with salinity, could favour their coexistence. As a result, the ecological and biological flexibility of the toothcarp should also be highlighted as facilitators of this coexistence in conditions similar to those found in the San Pedro channel.

Acknowledgements. We thank Institut d'Ecologia Aquàtica of the University of Girona for the study of the invertebrate community and for help in prey identification, J. Caravaca for help in field sampling and D. Verdiell-Cubedo for help in the analysis of data. We also thank M. Crim and J. Lloret for English revision of the manuscript, and anonymous reviewers for their valuable comments that greatly improved the manuscript. A. Ruiz-Navarro held a doctoral fellowship (FPU AP2006-01528) from the Spanish Ministry of Education.

\section{LITERATURE CITED}

Alcaraz C, García-Berthou E (2007a) Life history variation of invasive mosquitofish (Gambusia holbrooki) along a salinity gradient. Biol Conserv 139:83-92

> Alcaraz C, García-Berthou E (2007b) Food of an endangered cyprinodont (Aphanius iberus): ontogenetic diet shift and prey electivity. Environ Biol Fishes 78:193-207

- Alcaraz C, Bisazza A, García-Berthou E (2008a) Salinity mediates the competitive interactions between invasive mosquitofish and an endangered fish. Oecologia 155: 205-213

> Alcaraz C, Pou-Rovira Q, García-Berthou E (2008b) Use of a flooded salt marsh habitat by an endangered cyprinodontid fish (Aphanius iberus). Hydrobiologia 600:177-185

Arthington AH (1989) Diet of Gambusia affinis holbrooki, Xiphophorus helleri, X. maculatus and Poecilia reticulata (Pisces: Poeciliidae) in streams of southeastern Queensland, Australia. Asian Fish Sci 2:193-212

Blanco S, Romo S, Villena MJ (2004) Experimental study on the diet of mosquitofish (Gambusia holbrooki) under different ecological conditions in a shallow lake. Int Rev Hydrobiol 89:250-262
Caiola N, de Sostoa A (2005) Possible reasons for the decline of two native toothcarps in the Iberian Peninsula: evidence of competition with the introduced eastern mosquitofish. J Appl Ichthyology 21:358-363

> Carmona-Catot G, Magellan K, García-Berthou E (2013) Temperature-specific competition between invasive mosquitofish and an endangered cyprinodontid fish. PLoS ONE 8:e54734

> Carpentieri P, Colloca F, Ardizzone G (2007) Rhythms of feeding activity and food consumption of two Mediterranean burrowing fishes: Gnathophis mystax (Delaroche) and Chlopsis bicolor Rafinesque. PSZNI: Mar Ecol 28: 487-495

Chapman CP, Warburton K (2006) Postflood movements and population connectivity in gambusia (Gambusia holbrooki). Ecol Freshwat Fish 15:357-365

> Clavero M, Blanco-Garrido F, Prenda J (2007) Population and microhabitat effects of interspecific interactions on the endangered Andalusian toothcarp (Aphanius baeticus). Environ Biol Fishes 78:173-182

Costello MJ (1990) Predator feeding strategy and prey importance: a new graphical analysis. J Fish Biol 36: 261-263

García-Berthou E (1999) Food of introduced mosquitofish: ontogenetic diet shift and prey selection. J Fish Biol 55: 135-147

García-Berthou E (2007) The characteristics of invasive fishes: What has been learned so far? J Fish Biol 71(Suppl D):33-55

García-Berthou E, Moreno-Amich R (1993) Multivariate analysis of covariance in morphometric studies of the reproductive cycle. Can J Fish Aquat Sci 50:1394-1399

> Gascón S, Llopart X, Ruiz-Navarro A, Compte J and others (2013) The effects of Aphanius iberus predation on an aquatic community: diel changes and the role of vegetation. Fundam Appl Limnol 182:75-87

Gkenas C, Oikonomou A, Economou A, Kiosse F, Leonardos I (2012) Life history pattern and feeding habits of the invasive mosquitofish, Gambusia holbrooki, in Lake Pamvotis (NW Greece). J Biol Res Thessalon 17:121-136

- Gozlan RE, Britton JR, Cowx I, Copp GH (2010) Current knowledge on non-native freshwater fish introductions. J Fish Biol 76:751-786

Haas RC, Thomas MV, Towns GL (2003) An assessment of the potential use of Gambusia for mosquito control in Michigan. Technical report, Michigan Department of Natural Resources, Fisheries Division, Lansing, MI

> Harrison TD, Ramm AEL, Cerff EC (1986) A low-cost effective trap for use in sampling aquatic fauna. Aquaculture 58:145-149

> Haynes JL, Cashner RC (1995) Life history and population dynamics of the western mosquitofish: a comparison of natural and introduced populations. J Fish Biol 46: 1026-1041

> Homski D, Goren M, Gasith A (1994) Comparative evaluation of the larvivorous fish Gambusia affinis and Aphanius dispar as mosquito control agents. Hydrobiologia 284:137-146

- Horn HS (1966) Measurement of 'overlap' in comparative ecological studies. Am Nat 100:419-424

> Howe E, Howe C, Lim R, Burchett M (1997) Impact of the introduced poeciliid Gambusia holbrooki (Girard, 1859) on the growth and reproduction of Pseudomugil signifer (Kner, 1865) in Australia. Mar Freshw Res 48:425-434

IUCN (International Union for the Conservation of Nature) 
(2011) IUCN Red List of threatened species, Version 2011.2. www.iucnredlist.org (accessed 2 January 2012)

Keast A (1977) Diet overlaps and feeding relationships between the year classes in the yellow perch (Perca flavescens). Environ Biol Fishes 2:53-70

Law JM, Hawkins WE, Overstreet RM, Walker WW (1994) Hepatocarcinogenesis in western mosquitofish (Gambusia affinis) exposed to methylazoxymethanol acetate. J Comp Pathol 110:117-127

Leunda PM (2010) Impacts of non-native fishes on Iberian freshwater ichthyofauna: current knowledge and gaps. Aquat Invasions 5:239-262

- Margaritora FG, Ferrara O, Vagaggini D (2001) Predatory impact of the mosquitofish (Gambusia holbrooki Girard) on zooplanktonic populations in a pond at Tenuta di Castelporziano (Rome, Central Italy). J Limnol 60:189-193

Mills MD, Rader RB, Belk MC (2004) Complex interactions between native and invasive fish: the simultaneous effects of multiple negative interactions. Oecologia 141: 713-721

Miura T, Takahashi RM, Stewart RJ (1979) Habitat and food selection by the mosquitofish, Gambusia affinis. Proc Calif Mosq Vector Control Assoc 47:46-50

Moreno-Amich R, Pou Q, Quintana X, García-Berthou E (1999) Efecto de la regulación hídrica en la conservación del fartet (Lebias ibera) en Aiguamolls de L'Empordà: importancia de los refugios de población. In: PlanellesGomis M (coord) Peces Ciprinodóntidos Ibéricos Fartet y Samaruc. Conselleria de Medio Ambiente, Generalitat Valenciana, Valencia, p 115-131

Morillo-Velarde PS, Lloret J, Marín A, Sánchez-Vázquez FJ (2011) Effects of cadmium on locomotor activity rhythms of the amphipod Gammarus aequicauda. Arch Environ Contam Toxicol 60:444-451

Morisita M (1959) Measuring of interspecific association and similarity between communities. Memoirs of the Faculty of Science, Kyushu University, Series E 3:64-80

> Newman RM, Waters TF (1984) Size-selective predation on Gammarus pseudolimnaeus by trout and sculpins. Ecology 65:1535-1545

> Olden JD, Poff NLR, Bestgen KR (2006) Life-history strategies predict fish invasions and extirpations in the Colorado River Basin. Ecol Monogr 76:25-40

Oliva-Paterna FJ, Torralva M, Fernández-Delgado C (2006) Threatened fishes of the world: Aphanius iberus (Cuvier \& Valenciennes, 1846) (Cyprinodontidae). Environ Biol Fishes 75:307-309

Purcell KM, Hitch AT, Klerks PL, Leberg PL (2008) Adaptation as a potential response to sea-level rise: a genetic basis for salinity tolerance in populations of a coastal

Editorial responsibility: Asbjørn Vøllestad, Oslo, Norway marsh fish. Evol Appl 1:155-160

Pyke G (2005) A review of the biology of Gambusia affinis and G. holbrooki. Rev Fish Biol Fish 15:339-365

Pyke G (2008) Plague minnow or mosquito fish? A review of the biology and impacts of introduced Gambusia species. Annu Rev Ecol Evol Syst 39:171-191

Ribeiro F, Leunda PM (2012) Non-native fish impacts on Mediterranean freshwater ecosystems: current knowledge and research needs. Fish Manag Ecol 19:142-156

Rincón PA, Correas AM, Morcillo F, Risueño P, LobónCerviá J (2002) Interaction between the introduced eastern mosquitofish and two autochthonous Spanish toothcarps. J Fish Biol 61:1560-1585

Ruiz-Navarro A, Moreno-Valcárcel R, Torralva M, OlivaPaterna FJ (2011) Life-history traits of the invasive fish Gambusia holbrooki in saline streams (SE Iberian Peninsula): Does salinity limit its invasive success? Aquat Biol 13:149-161

- Ruiz-Navarro A, Verdiell-Cubedo D, Torralva M, OlivaPaterna FJ (2013) Dilution stress facilitates colonization of invasive mosquitofish in a saline Mediterranean stream: population biology response. Aquat Conserv 23:77-87

> Simpson EH (1949) Measurement of diversity. Nature 163: 688

Torralva M, Oliva-Paterna FJ, Andreu A, García-Mellado A and others (2001) Distribución y estado de conservación del fartet, Aphanius iberus (Valenciennes, 1846), en la Región de Murcia (S.E. de la Península Ibérica). Establecimiento de Grupos Poblacionales Operativos. Ann Biol 23:63-84

Trendall JT (1983) Life history variation among experimental populations of the mosquitofish, Gambusia affinis. Copeia 1983:953-963

Van Dolah RF (1978) Factors regulating the distribution and population dynamics of the amphipod Gammarus palustris in an intertidal salt marsh community. Ecol Monogr 48:191-217

> Vanderploeg HA, Scavia D (1979) Two electivity indices for feeding with special reference to zooplankton grazing. J Fish Res Board Can 36:362-365

Vargas MJ, de Sostoa A (1999) Ecología trófica del fartet, Lebias ibera, en el Delta del Ebro. In: Planelles-Gomis M (coord) Peces Ciprinodóntidos Ibéricos Fartet y Samaruc. Conselleria de Medio Ambiente, Generalitat Valenciana, Valencia, p 133-150

> Wallace RK (1981) An assessment of diet-overlap indexes. Trans Am Fish Soc 110:72-76

> Wurtsbaugh WA, Cech J (1983) Growth and activity of juvenile mosquitofish: temperature and ration effects. Trans Am Fish Soc 112:653-660

Submitted: November 30, 2012; Accepted: May 21, 2013 Proofs received from author(s): June 28, 2013 